\title{
Advanced Characterization of Organic Matter Decaying during Composting of Industrial Waste Using Spectral Methods
}

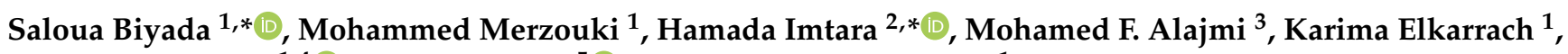 \\ Hamza Mechchate ${ }^{1,4} \mathbb{D}^{\mathbb{D}}$, Raffaele Conte ${ }^{5}{ }^{-}$and Mohamed Benlemlih ${ }^{1}$ \\ 1 Laboratory of Biotechnology, Environment, Agrifood and Health, Faculty of Sciences Dhar El Mahraz, BP: \\ 1796, Atlas, Sidi Mohamed Ben Abdellah University, Fez 30 000, Morocco; \\ mohammed.merzouki@usmba.ac.ma (M.M.); karima.elkarrach@usmba.ac.ma (K.E.); \\ Hamza.mechchate@usmba.ac.ma (H.M.); Mohamed.benlemlih@usmba.ac.ma (M.B.) \\ 2 Faculty of Arts and Sciences, Arab American University Palestine, Jenin P.O. Box 240, Palestine \\ 3 Department of Pharmacognosy, College of Pharmacy, King Saud University, Riyadh 11451, Saudi Arabia; \\ malajmii@ksu.edu.sa \\ 4 Laboratory of Inorganic Chemistry, Department of Chemistry, P.O. Box 55, FI-00014 Helsinki, Finland \\ 5 Research Institute on Terrestrial Ecosystems (IRET)—CNR, Via Pietro Castellino 111, 80131 Naples, Italy; \\ Raffaele.conte86@tiscali.it \\ * Correspondence: saloua.biyada@usmba.ac.ma (S.B.); hamada.tarayrah@gmail.com (H.I.)
}

check for updates

Citation: Biyada, S.; Merzouki, M.; Imtara, H.; Alajmi, M.F.; Elkarrach, K.; Mechchate, H.; Conte, R.; Benlemlih, M. Advanced Characterization of Organic Matter Decaying during Composting of Industrial Waste Using Spectral Methods. Processes 2021, 9, 1364. https://doi.org/ $10.3390 /$ pr9081364

Academic Editor: Antoni Sánchez

Received: 19 June 2021

Accepted: 28 July 2021

Published: 4 August 2021

Publisher's Note: MDPI stays neutral with regard to jurisdictional claims in published maps and institutional affiliations.

Copyright: (c) 2021 by the authors. Licensee MDPI, Basel, Switzerland. This article is an open access article distributed under the terms and conditions of the Creative Commons Attribution (CC BY) license (https:// creativecommons.org/licenses/by/ $4.0 /)$.

\begin{abstract}
To date, compost maturation monitoring is carried out by physical-chemical and microbiological analysis, which could be considered an overweening consumption of time and products. Nowadays, spectroscopy is chosen as a simple tool for monitoring compost maturity. In the present investigation, spectroscopy analysis was performed in the interest of corroborating the compost maturity. This goal was achieved by using the X-ray diffraction, infrared spectroscopy, and scanning electron microscopy. X-ray diffraction analysis showed the presence of the cellulose fraction in compost samples. At the same time, the intensity of pics decreased depending on composting time, thus proving that there was organic matter degradation. Infrared and scanning electron microscopy analysis allow for confirming these results. The correlation between spectroscopies analysis and physical-chemical properties was employed by partial least squares-regression (PLS-R) model. PLS-R model was applied to build a model to predict the compost quality depending on the composting time, the results obtained show that all the parameters analysis are well predicted. The current study proposed that final compost was more stabilized compared with the initial feedstock mixture. Ultimately, spectroscopy techniques used allowed us to confirm the physical-chemical results obtained, and both of them depict maturity and stability of the final compost, thus proving that spectral techniques are more reliable, fast, and promising than physical-chemical analyses.
\end{abstract}

Keywords: compost; textile waste; cellulose; spectroscopy analysis; scanning electron microscopy; PLS-R; maturity

\section{Introduction}

Over the past decades, the rising wealth of industry production has yielded a larger amount of waste produced each year. One of the most difficult environmental tasks for scientists is undoubtedly the management and disposal of industrial solid waste [1]. In Morocco, the textile industries are considered one of the industries producing a huge amount of solid waste, and that is disposed of directly into the environment without any treatment [2]. These wastes are a fountainhead of organic matter, which can be absolutely bio-converted into an organic fertilizer, thus contributing to enhance the soil quality [3], and therefore, reduce the risk of erosion if they are treated properly [4].

For many years, composting has shown efficiency in the sustainable management of solid waste wealthy in organic matter (carbon, nitrogen, and phosphorus, etc.) Furthermore, 
compost application to the soil allows the stimulation of microbial activity by rising microbial biomass activity, and therefore, their enzymatic reaction [5-8]. Composting is a stabilization and mineralization treatment of organic solid waste used to produce a stabilized compost $[1,9,10]$. A good management of composting process, from the feedstock to the final compost, is linked with optimum conditions.

Nonetheless, compost quality depends upon on its stability and maturity, and both must be monitored [4]. The intricacy of the composting process is assessed on the huge number of control variables (physical-chemical analysis, microbiological parameters, and enzymatic activities). These techniques are time consuming, and generally, more than one approach must be evaluated, which makes it difficult to assess the compost quality, thus favoring the exploration of new technologies for adequate assessing of the composting. Additionally, the maturity and stability of compost may also be achieved by spectroscopic analyses (X-ray diffraction, UV-Visible spectroscopy, infrared spectroscopy, scanning electron microscopy, etc.) These techniques are among the most reliable and promising methods for organic matter characterization as heterogeneous, thus providing complete information on functional and behavioral properties of samples [11].

In this regard, the use of spectroscopic methods has been suggested as a useful tool for assessing compost maturity. XRD analysis was usually used to investigate the organic matter transformation, especially that of cellulose, during composting. Infrared spectroscopy is a qualitative methods for assessing the organic matter functional groups [12]. Likewise, scanning electron microscopy (SEM) analysis was widely used to identify the morphological structure of compost that validates the final product stability and maturity. Recently, spectroscopic methods appear as a reliable tool for organic matter transformation prediction, particularly the decomposition of cellulose, during composting $[11,13]$.

To date, no investigations are present which include both traditional and advanced methods to assess the maturity and stability of textile waste with high concentration $(80 \%)$ during composting. The main goal of the current investigation was the establishment of an achievable technology to enhance the composting process monitoring of textile waste mixed with green waste, paper, and cardboard waste, using a rising amount of textile waste $(80 \%)$, by monitoring its degree of maturity using physical-chemical parameters as well as infrared spectroscopy, scanning electron microscopy, and XRD on the one hand. On the other hand is to evaluate the feasibility of spectroscopy analysis to predict the composting treatment and to identify the correlation between quantitative and qualitative chemical properties through textile waste composting using PLS-R model.

\section{Materials and Methods}

\subsection{Experimental Material}

The compost produced in the current investigation was carried out using as technique aerobic silo composting. It was composed of textile waste $(80 \%)$, green waste $(10 \%)$, and paper \& cardboard waste $(10 \%)$. Textile waste is obtained from MULTIWACH textile industry located in Fez (Morocco). Whereas green waste, paper, and cardboard waste was collected from the Faculty of Sciences, Dhar El Mahraz, Fez. Main characteristics of feedstock were illustrated in Table 1. Firstly, these wastes were mixed and placed in silo composter of $200 \mathrm{~L}$ (size $0.58 \times 0.58 \times 0.92 \mathrm{~m} \mathrm{~L} \times \mathrm{W} \times \mathrm{H}$ ) throughout 11 months. The silo composter was mixed and turned manually several times throughout these 11 months to promote organic matter humification. In order to have a representative and composite sample, samples were collected at different stages depending on three (0-20, 30-40, and $50-70 \mathrm{~cm}$ ) and four necessary positions (north, south, east, and west). 
Table 1. Feedstock physical-chemical characteristics.

\begin{tabular}{cccc}
\hline Physical-Chemical Parameters & Green Waste & Textile Waste & Paper and Cardboard Waste \\
\hline Moisture\% & $60.56 \pm 0.04$ & $50.26 \pm 0.05$ & $10.23 \pm 1.06$ \\
pH & $6.80 \pm 0.40$ & $7.30 \pm 0.11$ & $7.20 \pm 0.01$ \\
Total Organic Carbon\% & $44.56 \pm 0.60$ & $30.26 \pm 0.36$ & $40.26 \pm 0.04$ \\
Total Kjeldahl Nitrogen\% & $1.23 \pm 1.00$ & $0.53 \pm 0.80$ & $1.01 \pm 0.20$ \\
C/N Ratio & $36.22 \pm 0.01$ & $57.09 \pm 0.15$ & $39.86 \pm 0.18$ \\
\hline
\end{tabular}

Values designate mean \pm standard deviation based on 3 samples.

\subsection{Experimental Analysis}

\subsubsection{Physical-Chemical Analysis}

Ascertainment of moisture, temperature, ash, and $\mathrm{pH}$ were performed according to the method depicted by the French Association for Standardization [14]. From the percentage of total organic carbon (TOC) and the total nitrogen (TN). The $\mathrm{C} / \mathrm{N}$ ratio was calculated following the protocol provided by [15]. As for $\mathrm{Q}_{4} / \mathrm{Q}_{6}\left(\lambda_{472} / \lambda_{664}\right)$ absorbance ratio, analysis was performed according to the methods provided by [16]. Cellulose activity was measured according to [15]. Physical-chemical analysis was accomplished at various phases of composting (Initial, 3rd, 9th, and 11th months), these data of the same sample were published previously [15] (Table 2).

Table 2. Physical-Chemical properties changes throughout the composting process.

\begin{tabular}{|c|c|c|c|c|c|c|c|c|c|}
\hline $\begin{array}{c}\text { Time } \\
\text { (Months) }\end{array}$ & $\begin{array}{c}\text { TOC } \\
(\%)\end{array}$ & $\begin{array}{l}\text { TN } \\
(\%)\end{array}$ & C/N Ratio & $\mathrm{NH}_{4}{ }^{+} / \mathrm{NO}_{3}{ }^{-}$ & $\begin{array}{l}\text { Ash } \\
(\%)\end{array}$ & Moisture (\%) & $\begin{array}{c}\text { Temperature } \\
\left({ }^{\circ} \mathrm{C}\right)\end{array}$ & $\mathrm{pH}$ & $\begin{array}{l}\text { Cellulose } \\
\text { Activity } \\
\left(\mathrm{U} \mathrm{g}^{-1}\right)\end{array}$ \\
\hline Initial & $32.64 \pm 0.96$ & $0.56 \pm 0.04$ & 58.29 & 13.79 & 41.25 & $69.90 \pm 3.00$ & $10.50 \pm 2.10$ & $8.37 \pm 0.10$ & 0.41 \\
\hline 3 & $28.26 \pm 0.50$ & $0.76 \pm 0.01$ & 37.18 & 6.09 & 49.13 & $34.55 \pm 3.80$ & $25.00 \pm 2.00$ & $7.53 \pm 0.50$ & 30.55 \\
\hline 9 & $23.91 \pm 0.45$ & $1.17 \pm 0.04$ & 20.44 & 0.89 & 56.96 & $45.91 \pm 2.30$ & $42.00 \pm 2.90$ & $6.86 \pm 0.10$ & 42.59 \\
\hline 11 & $23.53 \pm 0.12$ & $1.10 \pm 0.02$ & 21.39 & 0.28 & 57.65 & $37.24 \pm 3.10$ & $29.00 \pm 1.20$ & $6.02 \pm 0.23$ & 5.84 \\
\hline
\end{tabular}

Values designate mean \pm standard deviation based on 3 samples.

\subsubsection{X-ray Diffraction Analysis}

$X$-ray diffraction $(X R D)$ analysis was carried out using $X^{\prime}$ Pert Pro diffractometer using $\mathrm{Cu} \mathrm{K} \alpha$ monochromatic radiation $(\lambda=1.5406 \AA)$, with a generator of $30 \mathrm{~mA}$ and $40 \mathrm{kV}$. The $2 \theta$ angle was between 5 and $70^{\circ}[17,18]$.

\subsubsection{Infrared Spectroscopy Analysis}

For each sample, $2 \mathrm{mg}$ of powder at various phases of composting (Ti: initial stage, T3: 3rd month, T9: 9th month, and T11: 11th month), were placed into a quartz-glass cell and analyzed with a IR-spectrometer (Bruker Vertex 70 spectrometer model) using a DTGS detector and OPUS 6.5 software, with wavenumber region between 400 and $4000 \mathrm{~cm}^{-1}$ with $2 \mathrm{~cm}^{-1}$ of resolution [12].

\subsubsection{Statistical Analysis}

Statistics analyses of the physical-chemical fractions of biomaterial compost were achieved. Mean, standard deviation (St. Dev.), coefficient of variation (CV \%), and a comparison of the means using the normalized analysis of variance (one-way ANOVA) were calculated. The PCA represent the correlation between chemical variables. Partial Least Squares-regression (PLS-R) was developed to correlate the chemical fractions of the compost samples with spectroscopy analyses. The PLS-R model is a multivariate linear calibration. In order to reduce the error margin, this model allows for minimizing large numbers of raw data into small sets of orthogonal factors among the values to be predicted. 


\section{Results and Discussion}

\subsection{Changes in Physical-Chemical Properties}

The physical-chemical properties of mature compost were found to differ considerably compared to the beginning of treatment. Table 2 depicts that the temperature increase rapidly through progression of the composting process to reach a maximum of $42{ }^{\circ} \mathrm{C}$ compared to the initial value, this increase could be owing to the microorganisms activities and their metabolic reactions [19-21]. At the end of the treatment, a decrease in temperature was depicted, which might be owing to the predominance of molecules, which are difficult to biodegrade by microorganisms (lignocellulosic, etc.) Furthermore, a decrease in moisture was observed with a value of $34.24 \%$, due to the evaporation of the water [15,22]. Regarding the $\mathrm{pH}$, a significant decrease was recorded through composting treatment, and it was 6.02 in final compost, as equated to 8.37 in feedstock mixture, this could be ascribed to the organic acids generation during composting $[15,23,24]$. Hence, the $\mathrm{pH}$ tended toward neutral range at the end of the process. A considerable decrease was detected for total organic carbon (TOC) by $23.53 \%$ in final compost in comparison to feedstock mixture. This decrease might be assigned to the organic matter mineralization. The low level of TOC in final compost revealed a huge amount of humic acid, thus indicating a good stabilization and maturation of the final compost [12,23]. Moreover, an increase of total nitrogen (TN) was recorded in the final compost $(1.10 \%)$ as contrasted to initial waste mixture $(0.56 \%)$. Rise in $\mathrm{TN}$ value could be assigned to nitrogenous substrate mineralization performed through microorganisms activities [25]. The $\mathrm{C} / \mathrm{N}$ ratio provides a general overview about compost stability and maturity levels. In the current study, $\mathrm{C} / \mathrm{N}$ ratio considerably decreased to $21.39 \%$ in final compost as contrasted to the pre-composted mixture. The mineralization of carbon and the release of $\mathrm{N}$ during progression of the composting process led to decreased $\mathrm{C} / \mathrm{N}$ ratio at the end of the process. Reducing in the $\mathrm{C} / \mathrm{N}$ ratio might be assigned to the rise in humification rate and degradation of recalcitrant molecules such as lignin, hemicelluloses, and cellulose during composting [24]. Additionally, C/ $\mathrm{N}$ ratio below 20 is considered a good index of compost stability [15], wherefore compost produced in the current investigation might be considered as stable and mature ( $\mathrm{C} / \mathrm{N}$ of $21.39 \%)$. The $\mathrm{NH}_{4}{ }^{+} / \mathrm{NO}_{3}{ }^{-}$ratio is widely used to show the compost maturity. $\mathrm{A} \mathrm{NH}_{4}{ }^{+} / \mathrm{NO}_{3}{ }^{-}$ratio of 0.22 was recorded at the end of the process, which is an indicative of acceptable maturity according several authors $[10,21]$. Cellulase activity determines overall microbial activity and organic substrate stabilization through the composting process. This activity was recorded as $0.41 \mathrm{U} \mathrm{g}^{-1}$ in initial feedstock mixture, which was increased to $42.59 \mathrm{U} \mathrm{g}^{-1}$ at the middle of composting and declined to $5.84 \mathrm{U} \mathrm{g}^{-1}$ in final compost. Rise in cellulose activity was assigned by several authors to microorganisms activities in the compost $[15,23]$. The substantial presence of cellulose activities towards the end of composting could be assigned to the formation of complexes between humic substances and cellulase enzymes, which is sheltered against denaturation and decaying [23]. Hence, it can be stated that composting of textile waste, even with high concentration of textile waste $(80 \%)$, has tremendous potential for valorization of plant nutrients from these wastes.

The $\mathrm{Q}_{4} / \mathrm{Q}_{6}\left(\lambda_{472} / \lambda_{664}\right)$ ratio depicts the degree of aromatic constituents' polymerization and might be considered a humification index. At the end, a decrease in this ratio was detected with a value of 8.9 compared to the initial value (66.00) (Table 3). Moreover, stabilization of this ratio at the end of treatment reflects an increase in humic substance, depicted by phenolic and benzenecarboxylic compounds. According to several authors, a $Q_{4} / Q_{6}$ ratio around 5 might be referring to the humified matter, thus justifying a noteworthy decrease in the $\mathrm{C} / \mathrm{N}$ ratio $[16,26]$. 
Table 3. Absorbance ratios evolution for the composting samples studied.

\begin{tabular}{cccc}
\hline Time (Months) & $\mathbf{A b s}_{\mathbf{4 7 2 n m}}$ & $\mathbf{A b s}_{\mathbf{6 6 4 n m}}$ & $\mathbf{Q}_{\mathbf{4}} / \mathbf{Q}_{\mathbf{6}}$ \\
\hline Initial & 0.20 & 0.003 & 66.00 \\
$\mathbf{3}$ & 0.44 & 0.030 & 14.67 \\
$\mathbf{9}$ & 0.70 & 0.080 & 8.75 \\
$\mathbf{1 1}$ & 0.80 & 0.090 & 8.89 \\
\hline
\end{tabular}

Values designate mean \pm standard deviation based on 3 samples.

\subsection{X-ray Diffraction Analysis}

Figure 1 depicts the XRD diffractograms for the compost samples at various composting stages (T3: 3rd month, T9: 9th month, and T11: 11th month) during textile waste composting. According X-ray diffractograms several peaks was depicted outspread over the range $2 \theta$ from $20^{\circ}$ to $50^{\circ}$, thus allowing identification of the majority of crystalline fraction of cellulose intensities $[27,28]$, with a noteworthy difference in intensity. X-ray diffractograms of samples analysis, indicating the attendance of the peaks attributed to the cellulose I fraction $\left(2 \theta=26.56^{\circ}\right)$ and to cellulose II $\left(2 \theta=34.50^{\circ}\right)$. In comparison to initial stage, the XRD spectra depicted significant lessening in the peak intensity at the end of composting, reflecting the decomposition of the cellulose polymer chains caused mainly by microorganisms through their enzymatic system, thus justifying the $\mathrm{C} / \mathrm{N}$ ratios reduction and therefore the increasing in the cellulose activity during composting, reflecting the cellulose compounds degradation $[18,27]$. Equally, peaks at $2 \theta=36.50^{\circ}, 40.25^{\circ}$, and $44.64^{\circ}$, attributed to calcium carbonate $\mathrm{CaCO}_{3}$ (inorganic fraction) was observed, thus confirming that there was an organic matter mineralization into inorganic constituents by microorganisms during composting.

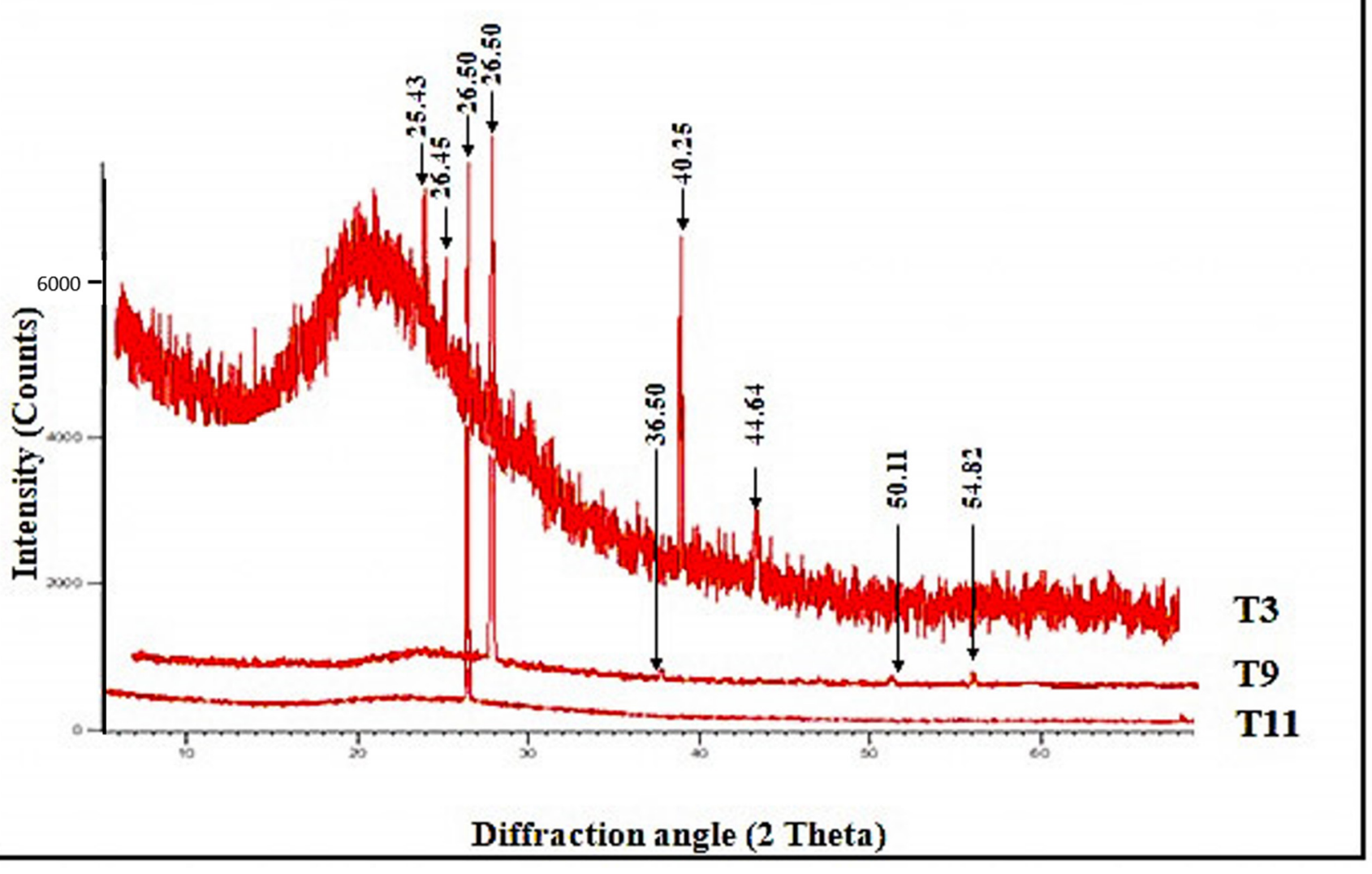

Figure 1. X-ray diffractogram of mixture at different stages of composting (T3: 3rd month, T9: 9th month and T11: 11th month). 


\subsection{Infrared Spectroscopy Analysis}

The chemical functional groups of organic matter was identified using infrared spectroscopy $[18,23]$. In Figure 2, the pertinent spectral bands of feedstock mix and final compost are depicted. The infrared (IR) absorptions assignment is summarized in Table 4. Spectra present in Figure 2 confirmed the presence of crystalline cellulose, as well as hemicellulose and lignin, through of the bands recorded in the range $3700-3100 \mathrm{~cm}^{-1}$. In comparison to feedstock mixture, final compost spectra depicted a considerable decreasing in the intensity of the peak at $3348 \mathrm{~cm}^{-1}$, thus indicating decaying by microorganisms of these compounds $[1,9,29,30]$. The band between $1700-1600 \mathrm{~cm}^{-1}$ owing to N-H bending vibrations attributed to Amide I in hemicelluloses and/or cellulosic in compost samples (Figure 2) [30]. The presence of mineral form was corroborated by the peak at $1399 \mathrm{~cm}^{-1}$, thus justifying the results obtained previously by XRD and Ash (Table 2). According to [12], cellulose in crystallized form is depicted in infrared spectrum by a small band at $1348 \mathrm{~cm}^{-1}$, thus proving the XRD results mentioned beforehand (Figure 1). The band appeared at $1120 \mathrm{~cm}^{-1}$, indicating the presence of lignin and carbohydrates [31,32]. Band between 1172 and $950 \mathrm{~cm}^{-1}$ was detected, which depicts the fingerprints region of cellulose and hemicelluloses. Additionally, a peak at $1030 \mathrm{~cm}^{-1}$ owing to aromatic compound and carbohydrates in compost samples was observed [27,33-35]. A prominent increase in this band was noticed, owing to raise levels of aromatic compound and polysaccharides [36]. These findings proved the decomposition of polysaccharides, aliphatic, and carbohydrates from the feedstock mixture, which corroborate that composting induced the cellulose degradation, whereas humic structures and aromatic compounds appeared towards the end of composting, showing its stability and maturity, and equally corroborate the results obtained by the physical-chemical analysis.

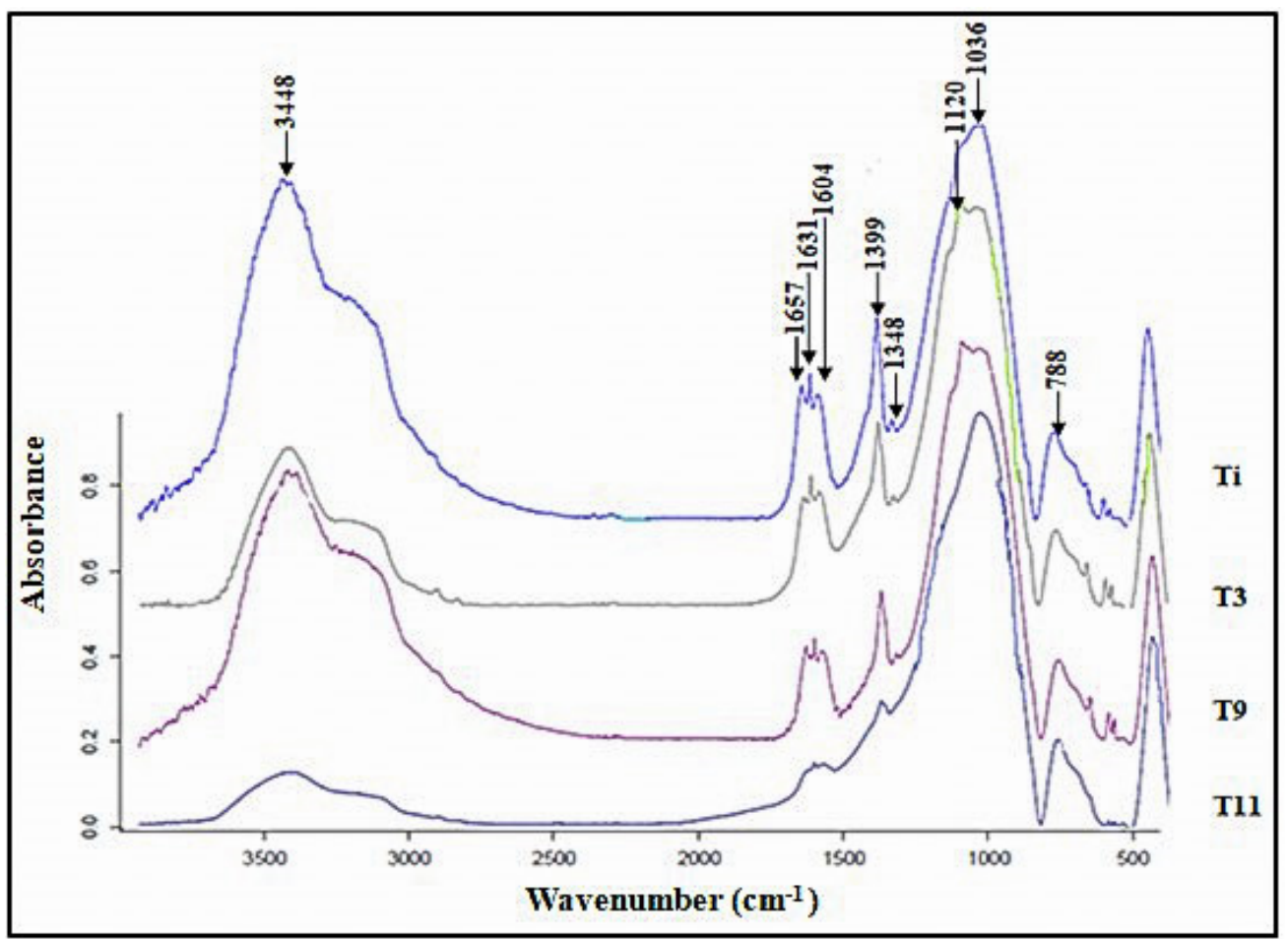

Figure 2. Infrared spectra indicating the evolution of compost samples at various stages of composting (T3: 3rd month, T9: 9th month and T11: 11th month). 
Table 4. Assignments of the main vibrations of the Infrared spectra.

\begin{tabular}{|c|c|}
\hline Wavenumber $\left(\mathrm{cm}^{-1}\right)$ & Band Assignements \\
\hline $3700-3000$ & $\begin{array}{c}\mathrm{v}(\mathrm{OH}) \text { hydroxyl groups in lignin, cellulose and hemicelluloses Intermolecular } \\
\text { hydrogen-bonded }\end{array}$ \\
\hline 1700-1600 & $\begin{array}{c}\mathrm{vC}=\mathrm{O} \text { ester in acetoxy groups }(\mathrm{H} 3 \mathrm{C}-(\mathrm{C}=\mathrm{O})-\mathrm{O}-) \text { in hemicellulose, } \mathrm{vC}=\mathrm{O} \text { in } \\
\text { quinone or p-quinone }\end{array}$ \\
\hline 1400-1300 & $\delta \mathrm{C}-\mathrm{H}$ and $\delta \mathrm{sCH} 3$ in cellulose and hemicelluloses \\
\hline 1120 & $\begin{array}{l}\mathrm{CH} \text { stretching vibrations in different groups of lignin and cellulose and } \\
\text { hemicelluloses }\end{array}$ \\
\hline 1030 & $\mathrm{C}-\mathrm{O}-\mathrm{C}$ stretching vibration of lignin and polysaccharides \\
\hline 787 & $\begin{array}{c}\mathrm{CH} 2 \text { rocking vibration in cellulose } \\
\text { (cellulose } \mathrm{I}_{\beta} \text { appear generally as a tiny peak at } 750 \mathrm{~cm}^{-1} \text { and } 3240 \mathrm{~cm}^{-1} \text { ) }\end{array}$ \\
\hline
\end{tabular}

\subsection{Scanning Electron Microscopy (SEM)}

Observations performed using scanning electron microscopy (SEM) allowed a gain of good knowledge of feedstock and final compost typical morphology. The morphological properties surface of compost samples were studied using SEM under 2000 magnification and illustrated in Figure 3a,b.

a.

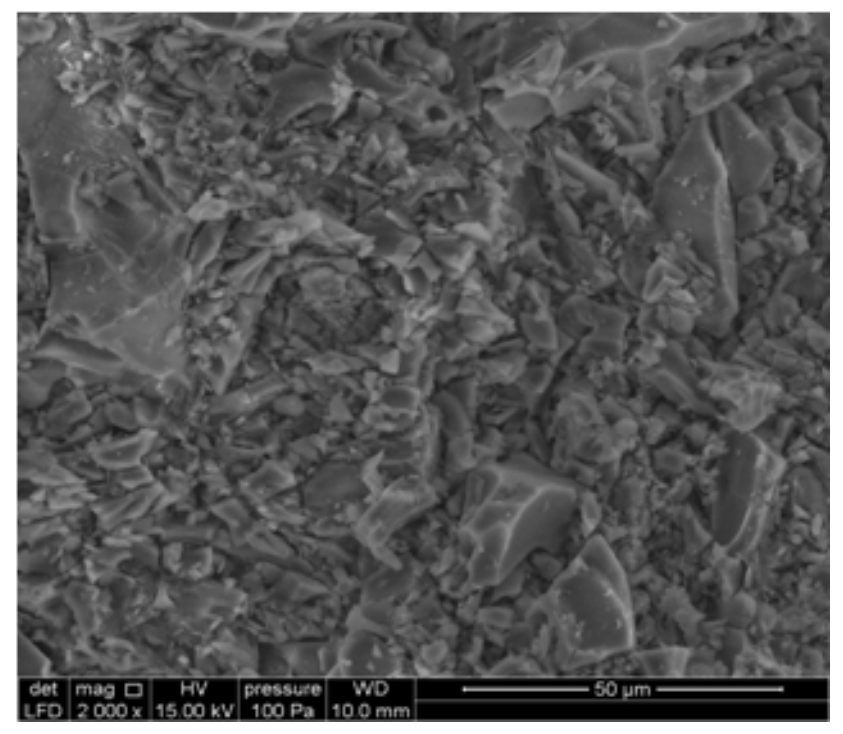

b.

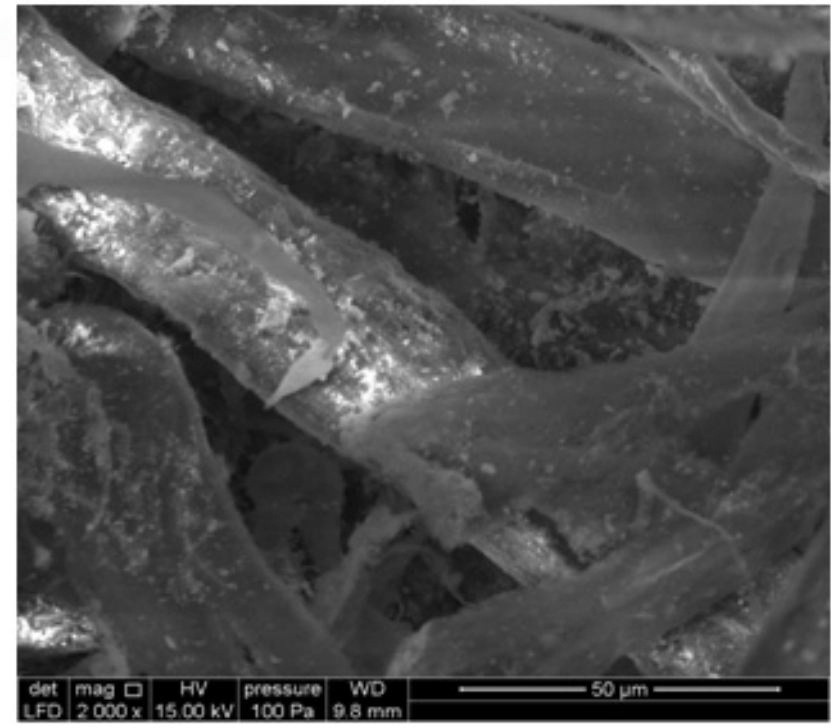

Figure 3. Scanning electron microscopy $(2000 \times)$ of $(\mathbf{a})$. pre-composted waste mixture and; (b). final compost.

The SEM Snapshots recorded of feedstock and final compost are compared in Figure 3a,b. The analysis depicted that the structure of the feedstock mixture was considerably compacted and flock, whilst a more granular, porous, and fragmented structure was depicted for the final compost (Figure 3a,b). Composting is a biological treatment based mainly on microorganism activity and their enzymatic systems. The disintegration of the substrate during composting was facilitated by various enzymes secreted (especially cellulose activity, etc.) by the microorganisms in the compost. Through Figure 3b, it can be noticed that final compost had fibrous structure; these fibers have different sizes and shapes, with diameters ranging between 5 and $45 \mu \mathrm{m}$, which corresponds, presumably, to cellulose fibers. The whole chains of fibers bundle together randomly, contributing to a heterogeneous network structure. These findings are consistent with various authors who used SEM analysis to highlight the modification that occurred in surface morphology of initial and final substrate composted [23,32,37]. 


\subsection{Statistical Analysis}

The factorial map depicted mixture samples of each age garnered showed by barycenter co-ordinates. The PC1 and PC2 reflected, respectively, $81.40 \%$ and $9.41 \%$ of the variance in spectral data (Figure 4). Using the PCA analysis, the chemical parameter of composts changed according to the composting stage. A chronological apportionment of samples on PC2 was observed. C, $\mathrm{N}, \mathrm{C} / \mathrm{N}$ ratio, $\mathrm{NH}_{4}{ }^{+} / \mathrm{NO}_{3}{ }^{-}$ratio, $\mathrm{Q}_{4} / \mathrm{Q}_{6}$ ratio, cellulose activity, $\mathrm{pH}, \mathrm{T}^{\circ}$, and Moisture arrows, pointed from old samples (44-week-old) to young composts (1-week-old). This finding could explain the change in $\mathrm{C} / \mathrm{N}$ ratio throughout composting. Several authors explain that the modification in $\mathrm{C} / \mathrm{N}$ ratio indicates the organic matter stabilization and decay $[7,12,38]$. Arrow of $\mathrm{C} / \mathrm{N}$, directed from old to young compost groups, shows the organic matter stabilization and strengthens the chronological distribution on PC2, and comparable outcomes were noticed by [4].

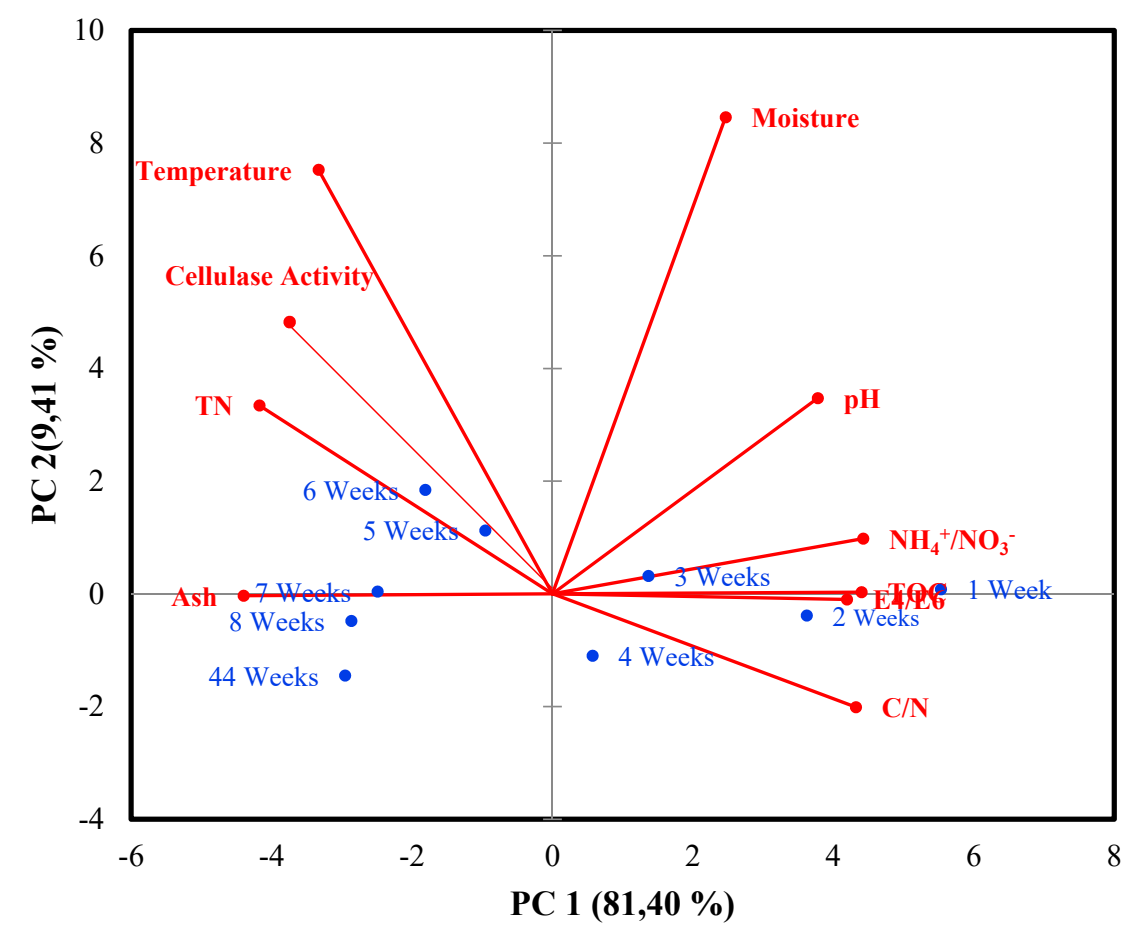

Figure 4. Results of PCA analysis. Each circle is the barycentre co-ordinate with standard deviation of each stage of composting. TOC: total organic carbon; TN: total nitrogen; $\mathrm{C} / \mathrm{N}$ : carbon/nitrogen ratio; $\mathrm{NH}_{4}{ }^{+} / \mathrm{NO}_{3}{ }^{-}$ratio: ammonium nitrogen /nitrate nitrogen; $\mathrm{Q}_{4} / \mathrm{Q}_{6}$ ratio: $472 / 664 \mathrm{~nm}$.

The main goal of the current investigation was to indicate the compost development of compost from a high concentration of textile waste $(80 \%)$. For this reason, the prediction of organic matter state depending upon time using infrared analysis to predicate $\mathrm{C}, \mathrm{N}$, $\mathrm{C} / \mathrm{N}, \mathrm{NH}_{4}{ }^{+} / \mathrm{NO}_{3}{ }^{-}, \mathrm{Q}_{4} / \mathrm{Q}_{6}$, Cellulose activity, $\mathrm{T}^{\circ}$, time of composting, and moisture was employed. The accurateness of the prediction model was estimated by several parameters. The $\mathrm{R}^{2}$ values were $0.98,0.98,0.98,0.97,0.79,0.98,0.77,0.37$, and 0.90 , respectively for $\mathrm{C}, \mathrm{N}, \mathrm{C} / \mathrm{N}, \mathrm{NH}_{4}{ }^{+} / \mathrm{NO}_{3}{ }^{-}, \mathrm{Q}_{4} / \mathrm{Q}_{6}$ ratio, cellulose activity, $\mathrm{T}^{\circ}$, moisture and composting time validates the model (Table 5), which prove that these parameters are well correlated with IR spectra. The RMSEP values were $0.58,0.07,3.10,0.64,5.02,1.26,3.89,7.88$, and 0.90 , respectively for $\mathrm{C}, \mathrm{N}, \mathrm{C} / \mathrm{N}, \mathrm{NH}_{4}{ }^{+} / \mathrm{NO}_{3}{ }^{-}, \mathrm{Q}_{4} / \mathrm{Q}_{6}$ ratio, $\mathrm{T}^{\circ}$, moisture, and time of composting, which is acceptable according several authors [38,39]. Moreover, comparable outcomes were noticed by [38,39]. Nonetheless, more selective criteria, such as the coefficient of variation and standard deviation, to assess the efficiency of infrared spectroscopy calibrations were used. Regarding the coefficient of variation $(\mathrm{CV} \%)$, the values were of $2.29,7.87,0.52,12.74,21.91,46.49,17.44,17.76$, and 33.04, respectively for $\mathrm{C}, \mathrm{N}, \mathrm{C} / \mathrm{N}$, $\mathrm{NH}_{4}{ }^{+} / \mathrm{NO}_{3}{ }^{-}, \mathrm{Q}_{4} / \mathrm{Q}_{6}$ ratio, $\mathrm{T}^{\circ}$, moisture, and time of composting. ANOVA test was used 
to depict the changes of the physical-chemical properties during textile waste composting. Significant differences ( $p$-value $<0.05$ ) were recorded for all physical-chemical parameters except moisture.

Table 5. Summary statistics of compost analytical parameters and Infrared spectra.

\begin{tabular}{|c|c|c|c|c|c|c|}
\hline & Mean & St. Dev. & CV (\%) & ANOVA $(p)$ & $R^{2}$ & RMSEP * \\
\hline Time & 5.75 & 1.90 & 33.04 & $<0.05$ & 0.90 & 1.35 \\
\hline TOC & 27.08 & 0.62 & 2.29 & $<0.05$ & 0.98 & 0.58 \\
\hline $\mathbf{T N}$ & 0.89 & 0.07 & 7.87 & 0.004 & 0.98 & 0.07 \\
\hline $\mathrm{C} / \mathrm{N}$ & 34.32 & 3.28 & 0.82 & 0.002 & 0.98 & 3.10 \\
\hline $\mathrm{NH}_{4}{ }^{+} / \mathrm{NO}_{3}{ }^{-}$ & 5.26 & 0.67 & 12.74 & $<0.05$ & 0.97 & 0.64 \\
\hline $\mathbf{T}^{\circ}$ & 23.62 & 4.12 & 17.44 & 0.045 & 0.77 & 3.89 \\
\hline Ph & 7.19 & 0.40 & 5.56 & $<0.05$ & 0.68 & 0.38 \\
\hline Moisture & 46.90 & 8.33 & 17.76 & $0.143 \mathrm{~ns}$ & 0.37 & 7.88 \\
\hline $\mathrm{Q}_{4} / \mathrm{Q}_{6}$ & 24.23 & 5.31 & 21.91 & 0.021 & 0.79 & 5.02 \\
\hline Cellulase activity & 19.85 & 9.23 & 46.49 & $<0.05$ & 0.98 & 1.26 \\
\hline
\end{tabular}

CV: coefficient of variation; Significance levels: ns: not significant; $p<0.05 ; R^{2}$ : coefficient of correlation; RMSEP *: root mean square error of prediction; TOC: total organic carbon; TKN: total Kjeldahl nitrogen; $\mathrm{C} / \mathrm{N}$ : carbon/nitrogen ratio; $\mathrm{NH}_{4}{ }^{+} / \mathrm{NO}_{3}{ }^{-}:$ammonium nitrogen /nitrate nitrogen; $\mathrm{Q}_{4} / \mathrm{Q}_{6}$ ratio: $472 / 664 \mathrm{~nm}$.

Through this model, the differentiation between the properties of the compost, the phases of organic matter transformation could be equally highlighted. Actually, it was demonstrated that this analysis may use it to predict $\mathrm{C} / \mathrm{N}$ and $\mathrm{TN}$ development in compost samples [38,39]. Nitrogen is considered the most important constituents in fertilizers, and, equally, it is a very important element present in textile, paper and cardboard, and green waste. At the beginning, a part of the nitrogen content in composted wastes has undergone volatilization into air during the composting process [40]. At the next phase, organic $\mathrm{N}$ was transformed to ammonium and nitrate- $\mathrm{N}$ by microorganisms, thus raising the amount of nitrate-N, making it effective as a nitrogen fertilizer. The capacity to predict TN concentration in compost samples was strong and accurate. Moreover, $\mathrm{C} / \mathrm{N}$ ratio is widely used as a good and reliable tool to determine the maturity of compost; the PLS-R model was more successful for the compost samples. Additionally, $Q_{4} / Q_{6}$ ratio is considered, by several authors, as a good humification index, the predictions of this parameter was strong (Table 5) $[12,38,39]$. Commonly, the restoring of the predicted results depending upon the time depicted that no differences recorded between the measured and predicted values for the majority of the parameters (Figure 5). This investigation strengthened the chronological apportionment of compost provided by PCA following an advance of composting maturity. Another advantage of this investigation was to predict time of composting using different composts samples.
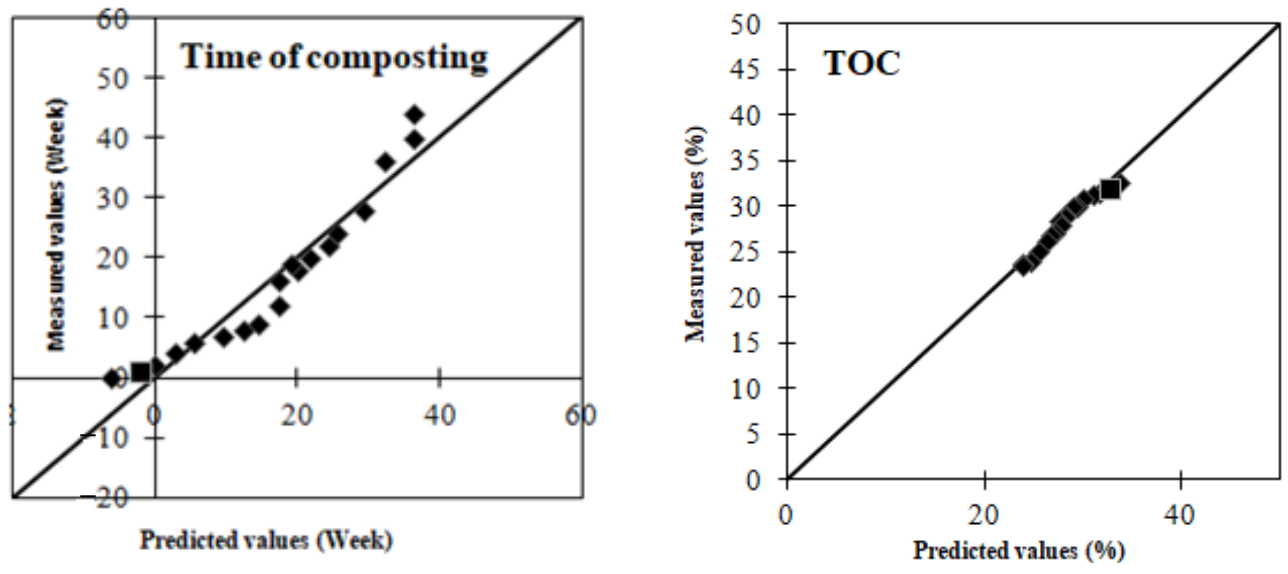

Figure 5. Cont. 

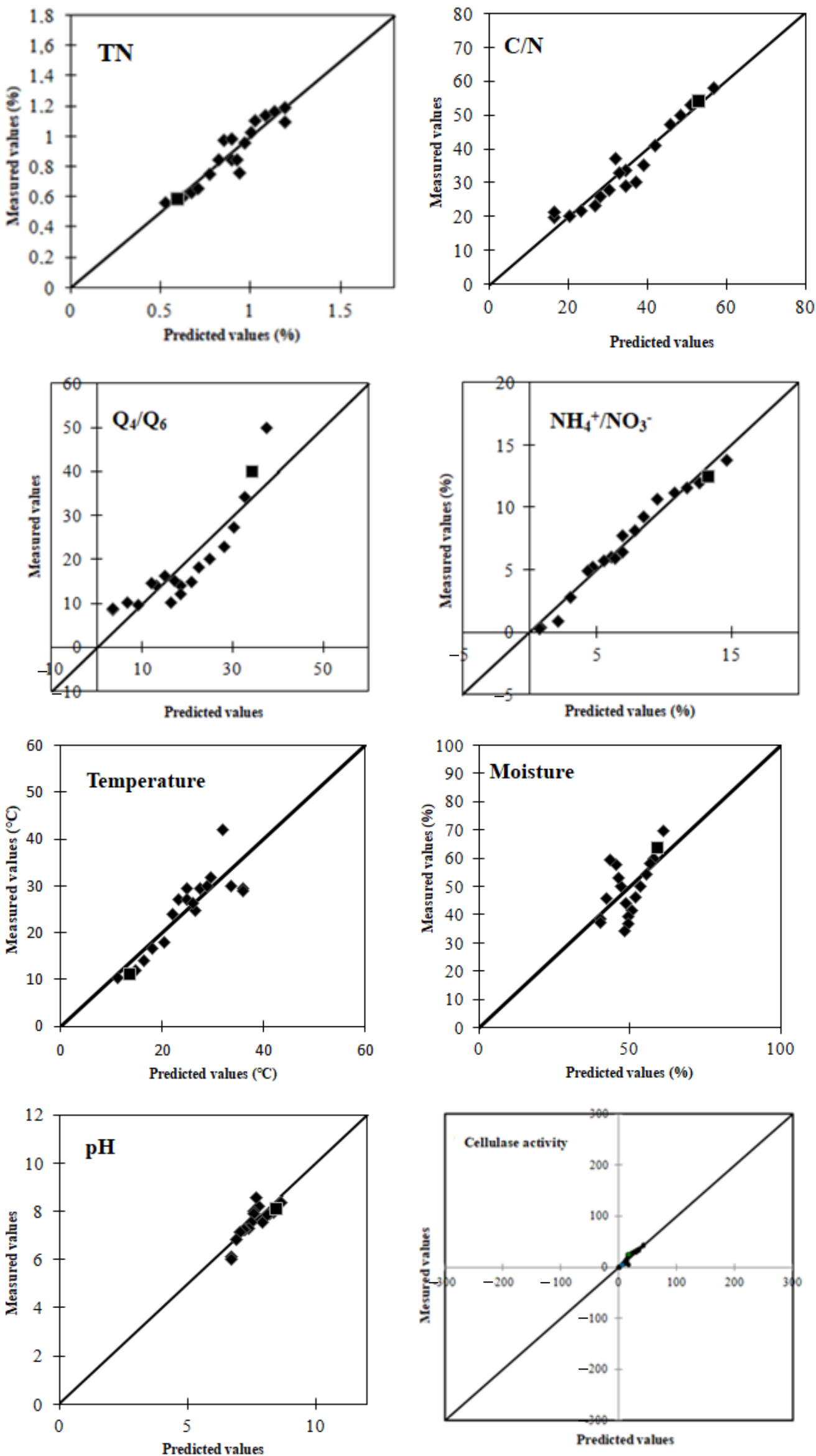

Figure 5. Prediction of the model using the partial least squares-regression. 


\section{Conclusions}

This study aimed to evaluate the applicability of spectral techniques to characterize the compost quality from textile waste even with a high concentration of this waste $(80 \%)$. For this reason, quantitative and qualitative physical-chemical parameters of compost samples were correlated with spectral analysis. A decrease in aliphatic compounds was observed in contrast to aromatic compounds, throughout solid waste decaying corroborated by XRD analysis. In addition, SEM micrographs depicted relatively larger areas and a plenty fibrous structure of final compost, thus proving cellulose fibers decaying. The current study provides an advance technique to prove compost maturity and stability from a huge concentration of textile waste. Ultimately, through this investigation, it can be concluded that the compost produces meet the required level of maturity.

Author Contributions: Conceptualization, S.B. and M.M.; methodology, S.B., M.M., H.I., H.M., K.E.; validation, M.M. and S.B. Data curation, S.B.; Formal analysis, S.B.; Investigation, S.B.; writingoriginal draft preparation, S.B.; Review and editing S.B., M.M., M.F.A. and R.C. Supervision, M.M. and M.B.; Funding acquisition, M.F.A., R.C. All authors have read and agreed to the published version of the manuscript.

Funding: This research was funded by Researchers Supporting Project number RSP-2021/122, King Saud University, Riyadh, Saudi Arabia.

Institutional Review Board Statement: Not applicable.

Informed Consent Statement: Not applicable.

Data Availability Statement: The data presented in this study are available on request from the corresponding author.

Acknowledgments: The authors acknowledge the generous support from researchers supporting project-under the group number (RSP-2021/122), King Saud University, Riyadh, Saudi Arabia; and the National Center for Scientific Research in Rabat (CNRST). The authors are gratefully acknowledged to BOUKIR Abdellatif from Faculty of Sciences and Techniques Fez for support and help.

Conflicts of Interest: The authors declare no conflict of interest.

\section{References}

1. Zahra El Ouaqoudi, F.; El Fels, L.; Lemée, L.; Amblès, A.; Hafidi, M. Evaluation of Lignocelullose Compost Stability and Maturity Using Spectroscopic (FTIR) and Thermal (TGA/TDA) Analysis. Ecol. Eng. 2015, 75, 217-222. [CrossRef]

2. Talouizte, H.; Merzouki, M.; Benlemlih, M. Treatment of Real Textile Wastwater Using SBR Technology: Effect of Sludge Age and Operational Parameters. J. Biotechnol. Lett. 2017, 4, 79-83.

3. Pagliai, M.; Vignozzi, N.; Pellegrini, S. Soil Structure and the Effect of Management Practices. Soil Tillage Res. 2004, 79, 131-143. [CrossRef]

4. Albrecht, R.; Joffre, R.; Gros, R.; Le Petit, J.; Terrom, G.; Périssol, C. Efficiency of Near-Infrared Reflectance Spectroscopy to Assess and Predict the Stage of Transformation of Organic Matter in the Composting Process. Bioresour. Technol. 2008, 99, 448-455. [CrossRef]

5. Wu, H.; Zhao, Y.; Long, Y.; Zhu, Y.; Wang, H.; Lu, W. Evaluation of the Biological Stability of Waste during Landfill Stabilization by Thermogravimetric Analysis and Fourier Transform Infrared Spectroscopy. Bioresour. Technol. 2011, 102, 9403-9408. [CrossRef]

6. Albrecht, R.; Le Petit, J.; Calvert, V.; Terrom, G.; Périssol, C. Changes in the Level of Alkaline and Acid Phosphatase Activities during Green Wastes and Sewage Sludge Co-Composting. Bioresour. Technol. 2010, 101, 228-233. [CrossRef]

7. Crecchio, C.; Curci, M.; Pizzigallo, M.D.R.; Ricciuti, P.; Ruggiero, P. Effects of Municipal Solid Waste Compost Amendments on Soil Enzyme Activities and Bacterial Genetic Diversity. Soil Biol. Biochem. 2004, 36, 1595-1605. [CrossRef]

8. Peláez, C.; Mejía, A.; Planas, A. Development of a Solid Phase Kinetic Assay for Determination of Enzyme Activities during Composting. Process Biochem. 2004, 39, 971-975. [CrossRef]

9. Vergnoux, A.; Guiliano, M.; Le Dréau, Y.; Kister, J.; Dupuy, N.; Doumenq, P. Monitoring of the Evolution of an Industrial Compost and Prediction of Some Compost Properties by NIR Spectroscopy. Sci. Total Environ. 2009, 407, 2390-2403. [CrossRef]

10. Aguelmous, A.; Lahsaini, S.; El Fels, L.; Souabi, S.; Zamama, M.; Hafidi, M. Biodegradation Assessment of Biological Oil Sludge from a Petroleum Refinery. J. Mater. Environ. Sci. 2016, 7, 3421-3430.

11. Temporal-lara, B.; Melendez-pastor, I.; Gómez, I.; Navarro-pedreño, J. Wastewater Biosolid Composting Optimization Based on UV-VNIR Spectroscopy Monitoring. Sensors 2016, 16, 1919. [CrossRef]

12. Ilani, T.; Herrmann, I.; Karnieli, A.; Arye, G. Characterization of the Biosolids Composting Process by Hyperspectral Analysis. Waste Manag. 2016, 48, 106-114. [CrossRef] 
13. Ueno, M.; Taira, E.; Kawamitsu, Y.; Komiya, Y.; Kikuchi, K. Application of FT-NIR Spectroscopy to the Evaluation of Compost Quality. Eng. Agric. Environ. Food 2008, 1, 51-56. [CrossRef]

14. Afnor. Amendements du sol et Support de Culture-Préparation des Echantillons Pour les Essais Physiques et Chimiques, Détermination de la Teneur en Matière Sèche, du Taux D'humidité et de la Masse Volumique Compactée en Laboratoire; The French Association for Standardization: Paris, France, 2000.

15. Biyada, S.; Merzouki, M.; Demcenko, T.; Vasiliauskiene, D.; Urbonavicius, J.; Marciulaitiene, E.; Vasarevicius, S.; Benlemlih, M. Evolution of Microbial Composition and Enzymatic Activities during the Composting of Textile Waste. Appl. Sci. 2020, 10, 3758. [CrossRef]

16. Albrecht, R.; Le Petit, J.; Terrom, G.; Périssol, C. Comparison between UV Spectroscopy and Nirs to Assess Humification Process during Sewage Sludge and Green Wastes Co-Composting. Bioresour. Technol. 2011, 102, 4495-4500. [CrossRef] [PubMed]

17. Boukir, A.; Mehyaoui, I.; Fellak, S.; Asia, L.; Doumenq, P. The Effect of the Natural Degradation Process on the Cellulose Structure of Moroccan Hardwood Fiber: A Survey on Spectroscopy and Structural Properties. Mediterr. J. Chem. 2019, 8, 179-190. [CrossRef]

18. Boukir, A.; Fellak, S.; Doumenq, P. Structural Characterization of Argania Spinosa Moroccan Wooden Artifacts during Natural Degradation Progress Using Infrared Spectroscopy (ATR-FTIR) and X-ray Diffraction (XRD). Heliyon 2019, 5, e02477. [CrossRef]

19. Wang, K.; Li, W.; Gong, X.; Li, Y.; Wu, C.; Ren, N. Spectral Study of Dissolved Organic Matter in Biosolid during the Composting Process Using Inorganic Bulking Agent: UV e Vis, GPC, FTIR and EEM. Int. Biodeterior. Biodegrad. 2013, 85, 617-623. [CrossRef]

20. Abdel-Rahman, M.A.; Nour El-Din, M.; Refaat, B.M.; Abdel-Shakour, E.H.; Ewais, E.E.D.; Alrefaey, H.M.A. Biotechnological Application of Thermotolerant Cellulose-Decomposing Bacteria in Composting of Rice Straw. Ann. Agric. Sci. 2016, 61, 135-143. [CrossRef]

21. Hachicha, R.; Hachicha, S.; Trabelsi, I.; Woodward, S.; Mechichi, T. Evolution of the Fatty Fraction during Co-Composting of Olive Oil Industry Wastes with Animal Manure: Maturity Assessment of the End Product. Chemosphere 2009, 75, 1382-1386. [CrossRef]

22. López-gonzález, J.A.; Vargas-garcía, M.C.; López, M.J.; Suárez-estrella, F.; Jurado, M.; Moreno, J. Biodiversity and Succession of Mycobiota Associated to Agricultural Lignocellulosic Waste-Based Composting. Bioresour. Technol. 2015, 187, 305-313. [CrossRef]

23. Srivastava, V.; Goel, G.; Kumar, V.; Pratap, R.; De Araujo, A.S.F.; Singh, P. Analysis and Advanced Characterization of Municipal Solid Waste Vermicompost Maturity for a Green Environment. J. Environ. Manag. 2020, 255, 109914. [CrossRef]

24. Soobhany, N.; Gunasee, S.; Pooja, Y.; Joyram, H.; Raghoo, P. Spectroscopic, Thermogravimetric and Structural Characterization Analyses for Comparing Municipal Solid Waste Composts and Vermicomposts Stability and Maturity. Bioresour. Technol. 2017, 236, 11-19. [CrossRef]

25. Sharma, A.; Ganguly, R.; Kumar, A. Spectral Characterization and Quality Assessment of Organic Compost for Agricultural Purposes. Int. J. Recycl. Org. Waste Agric. 2019, 8, 197-213. [CrossRef]

26. Amir, S.; Hafidi, M.; Merlina, G.; Revel, J.C. Structural Characterization of Fulvic Acids during Composting of Sewage Sludge. Process Biochem. 2005, 40, 1693-1700. [CrossRef]

27. Hajji, L.; Boukir, A.; Assouik, J.; Luis, J.; Luisa, M. Artificial Aging Paper to Assess Long-Term Effects of Conservative Treatment. Monitoring by Infrared Spectroscopy (ATR-FTIR), X-ray Diffraction (XRD), and Energy Dispersive X-ray Fl Uorescence (EDXRF) . Microchem. J. 2016, 124, 646-656. [CrossRef]

28. Hajji, L.; Boukir, A.; Assouik, J.; Lakhiari, H.; Kerbal, A.; Doumenq, P.; Mille, G.; Luisa, M.; Carvalho, D. Conservation of Moroccan Manuscript Papers Aged 150, 200 and 800 Years. Analysis by Infrared Spectroscopy (ATR-FTIR), X-ray Diffraction (XRD), and Scanning Electron Microscopy Energy Dispersive Spectrometry (SEM-EDS). Spectrochim. Acta Part A Mol. Biomol. Spectrosc. 2015, 136, 1038-1046. [CrossRef]

29. Lim, S.L.; Wu, T.Y. Determination of Maturity in the Vermicompost Produced from Palm Oil Mill Effluent Using Spectroscopy, Structural Characterization and Thermogravimetric Analysis. Ecol. Eng. 2015, 84, 515-519. [CrossRef]

30. Garriga, P.; Colom, X.; Carrillo, F.; Nogue, F. Structural Analysis of Photodegraded Wood by Means of FTIR Spectroscopy. Polym. Degrad. Stab. 2003, 80, 543-549. [CrossRef]

31. Zghari, B.; Doumenq, P.; Romane, A.; Boukir, A. GC-MS, FTIR and 1 H, 13 C NMR Structural Analysis and Identification of Phenolic Compounds in Olive Mill Wastewater Extracted from Oued Oussefrou Effluent (Beni Mellal-Morocco). J. Mater. Environ. Sci. 2017, 8, 4496-4509.

32. Hajji, L.; Boukir, A.; Assouik, J.; Kerbal, A.; Kajjout, M. A Multi-Analytical Approach for the Evaluation of the Efficiency of the Conservation-Restoration Treatment of Moroccan Historical Manuscripts Dating to the 16th, 17th, and 18th Centuries. Appl. Spectrosc. 2015, 69, 920-938. [CrossRef] [PubMed]

33. Makarem, M.; Lee, C.M.; Kafle, K.; Huang, S.; Chae, I.; Yang, H.; Kubicki, J.D.; Kim, S.H. Probing Cellulose Vibrational Spectroscopy; Springer: Dordrecht, The Netherlands, 2019; ISBN 1057001821.

34. Acharya, S.; Hu, Y.; Moussa, H.; Abidi, N. Preparation and Characterization of Transparent Cellulose Films Using an Improved Cellulose Dissolution Process. J. Appl. Polym. Sci. 2017, 44871, 1-12. [CrossRef]

35. Falcão, L.; Araújo, M.E.M. Application of ATR-FTIR Spectroscopy to the Analysis of Tannins in Historic Leathers: The Case Study of the Upholstery from the 19th Century Portuguese Royal Train. Vib. Spectrosc. 2014, 74, 98-103. [CrossRef]

36. Droussi, Z.; Valeria, D.; Rosaria, M.; Hafidi, M.; Ouatmane, A. Study of the Biodegradation and Transformation of OliveMill Residues during Composting Using FTIR Spectroscopy and Differential Scanning Calorimetry. J. Hazard. Mater. 2009, 164, 1281-1285. [CrossRef] 
37. Katusiimeh, M.W.; Burger, K.; Mol, A.P.J. Informal Waste Collection and Its Co-Existence with the Formal Waste Sector: The Case of Kampala, Uganda. Habitat Int. 2013, 38, 1-9. [CrossRef]

38. Chang, C.; Laird, D.A. Near-Infrared Reflectance Spectroscopic Analysis of Soil c and n. Soil Sci. 2002, 167, 110-116. [CrossRef]

39. Malley, D.F.; Mcclure, C.; Martin, P.D. Compositional Analysis of Cattle Manure During Composting Using a Field-Portable Near-Infrared Spectrometer. Commun. Soil Sci. Plant Anal. 2005, 36, 455-475. [CrossRef]

40. Jouraiphy, A.; Amir, S.; El Gharous, M.; Revel, J.C.; Hafidi, M. Chemical and Spectroscopic Analysis of Organic Matter Transformation during Composting of Sewage Sludge and Green Plant Waste. Int. Biodeterior. Biodegrad. 2005, 56, 101-108. [CrossRef] 